\title{
A NEW SPECIES OF GAEOLAELAPS EVANS AND TILL (MESOSTIGMATA: LAELAPIDAE) FROM ZANZIBAR
}

\author{
Omid Joharchi ${ }^{1,2,3^{*}}$, Alexander A. Khaustov ${ }^{1}$ and Sergey G. Ermilov ${ }^{1}$ \\ ${ }^{1} \mathrm{X}$-BIO Institute, Tyumen State University, Tyumen, Russia \\ ${ }^{2}$ Department of Plant Protection, Yazd Branch, Islamic Azad University, Yazd, Iran \\ ${ }^{3}$ Department of Plant Protection, Science and Research Branch, Islamic Azad University, \\ Tehran, Iran \\ *corresponding author; e-mail: j.omid2000@gmail.com
}

ABSTRACT: A new mite species of the genus Gaeolaelaps (Laelapidae) collected from soil-litter in Zanzibar, Tanzania, is described and illustrated based on morphological characters of adult females. Gaeolaelaps bochkovi sp. n. has the unusual character state of a three-tined palp tarsal apotele.

KEY WORDS: Mites, Gamasina, taxonomy, Parasitiformes, Ethiopian region, Afrotropical region, Tanzania.

DOI: 10.21684/0132-8077-2019-27-2-221-227

\section{INTRODUCTION}

Mites of the family Laelapidae Berlese (Acari: Parasitiformes) are some of the most diverse mites among the families of the order Mesostigmata. The cosmopolitan genus Gaeolaelaps Evans and Till, 1966 comprises more than 100 described species distributed worldwide (Joharchi et al. 2019a, b, c). The wildlife of Zanzibar (also known as Unguja), is characterized by very rich terrestrial and marine flora and fauna. This fact is due to its special topographic and climatic heterogeneity. Zanzibar was separated from mainland Africa by a sea-level rise as recently as 10,000 years ago (Prendergast et al. 2016). However, its fauna has changed dramatically since then as a result of colonization by humans and the extinction of most species of large native mammals (Walsh 2007). The laelapid fauna of East Africa (especially Zanzibar) is poorly documented (Van Aswegen and Loots 1970, Joharchi et al. 2018). The present paper is a part of an ongoing project, which aims to raise the knowledge of regional fauna of laelapid mites, based on extensive recent collections of free-living species.

\section{MATERIALS AND METHODS}

The mites were extracted from soil and litter samples using Berlese-Tullgren funnels. Specimens were cleared in lactic acid solution and mounted in Hoyer's medium (Walter and Krantz 2009). The line drawings and examinations of the specimens were performed with a Zeiss Axio Imager A2 and a Leica DM 2500 compound microscopes equipped with differential interference contrast and phase contrast optical systems, attached to cameras AxioCam ICc 5 and ICC50 HD, respectively. The figures were elaborated with Adobe Photoshop CS2 software based on the line drawings. The images and morphological measurements were taken via ZEN 2012 software (v. 8.0) and Leica Application Suite (LAS) software (v. 4.2, Live and Interactive Measurements modules). The photomicrographs were taken with an AxioCam 506 camera (Carl Zeiss, Germany). The measurements of structures are expressed as ranges (minimum-maximum) in micrometres $(\mu \mathrm{m})$. The length and width of the dorsal shield were taken from the anterior to posterior margins along the midline, and at the level of $r 3$, respectively. The length and width of the sternal shield were measured at the maximum length and broadest points (at level of endopodal between coxae II and III), respectively. The length of the genital shield was measured along the midline from the anterior margin of the hyaline extension to the posterior margin of the shield, and its width (where maximal)—posteriorly to genital setae st 5 . The leg length was measured from the base of the coxa to the apex of the tarsus (excluding the pre-tarsus). The nomenclature used for the dorsal idiosomal chaetotaxy follows that of Lindquist and Evans (1965), the notations for leg and palp setae follow those of Evans (1963a, 1963b), and the other anatomical structures mostly follow Evans and Till (1979). Notations for idiosomal pore-like structures (gland pores and poroids/lyrifissures) and peritrematal shield follow mostly Athias-Henriot (1971, 1975), and the notation of pore-like structures on the sternal shield and peritrematal shield region also follow modifications and additions by Johnston and Moraza (1991), adapted by Kazemi et al. (2014). 
The holotype and paratypes of the new species are deposited at the acarological collection of the Tyumen State University Museum of Zoology, Tyumen, Russia (TSUMZ).

\section{SYSTEMATICS}

Genus Gaeolaelaps Evans and Till, 1966

Hypoaspis (Gaeolaelaps) Evans and Till 1966: 159.

Type species: Laelaps aculeifer Canestrini, 1884, by original designation (Evans and Till 1966).

Diagnosis. The concept of Gaeolaelaps used here is based on that of Beaulieu (2009) with modifications by Kazemi et al. (2014).

\section{Gaeolaelaps bochkovi sp. $\mathrm{n}$.}

(Figs. 1-3)

Diagnosis (female). Dorsal shield with weak reticulation, more distinct in opisthonotal and lateral regions, bearing 39 pairs of setae, 22 pairs of podonotal setae and 17 pairs of opisthonotal setae, including two pairs of $Z x$ setae. Podonotal setae longer (22-27), except $z 1, s 1$ (10-12), dorsal shield setae decreasing in length from anterior to posterior, almost all opisthonotal setae minute (11-16 long), except Z5 (28-30). Presternal area lightly sclerotized, with a few transverse curved lines. Sternal and genital shields elongate, sternal shield with reticulate ornamentation throughout, except a longitudinally central part of shield smooth (or faintly reticulated), posterior margin slightly convex and anterior margin undulating; bearing three pairs of smooth pointed setae, ratio of shield length/ width (at broadest level) $\simeq 0.96$. Genital shield ratio of length/width (at broadest level) $\simeq 1.76$, posterior margin of genital shield rounded, reaches anterior margin of anal shield, shield reticulate ornamentation throughout, comprising elongated oblique irregular cells. Anal shield with length/ width ratio (at broadest level) $\simeq 1.14$. Opisthosomal integument with 14 pairs of smooth setae (including r6), peritremes long, reaching to midlevel of coxae I. Tarsus IV with elongate setae ( $a d 2$, $p d 2$ 45-50). Palp tarsal apotele three-tined and fixed digit of chelicera with 9-10 teeth.

Description. Female $(\mathrm{n}=15)$.

Dorsal idiosoma (Figs. 1A, 2A). Dorsal shield oval-shaped, 350-360 long, 206-210 wide, covering well dorsal idiosoma; shield with weak reticulation, more distinct in opisthonotal and lateral regions, bearing 39 pairs of setae, 22 pairs of podonotal setae and 17 pairs of opisthonotal setae, including two pairs of $Z x$ setae and one unpaired supernumerary setae $J x$. Podonotal setae longer (22-27), except $z l, s 1$ (10-12) very short, dorsal shield setae decreasing in length from anterior to posterior, all opisthonotal setae minute (11-16 long), except Z5 (28-30) (Figs. 1A, 2A). Shield with about 21 pairs of discernible pore-like structures, including 15 poroids (id1, id2, id4, id5, $i d m 1-i d m 6, i d x$, is 1, idl1, idl3,idl4) and six gland openings ( $g d 1, g d 2, g d 5, g d 6, g d 8, g d 9)$, others indistinct (Figs. 1A, 2A).

Ventral idiosoma (Figs. 1B, 2B). Tritosternum with paired pilose laciniae (55-60), fused basally (2-4), columnar base 17-19 $\times 10-12$ wide; presternal area lightly sclerotized, with a few transverse curved lines. Sternal shields elongated (length 116-122), narrowest between coxae II (75-83), widest (119-126), posterior margin slightly convex and anterior margin undulating; bearing three pairs of smooth setae (st1 30-32, st2 30-32, st3 25-29), setae not reaching base of next setae, one pair of lyrifissures adjacent to setae $s t$, and a pair of poroids between $s t 2$ and $s t 3$; sternal shield with reticulate ornamentation throughout, except a longitudinally central part of shield smooth (or faintly reticulated). Metasternal setae st4 (24-26) and metasternal poroids located on soft integument; metasternal platelets absent. Endopodals plates I/II and II/III fused to anterolateral angles of sternal shield and sternal shield, respectively, endopodal plates III/IV elongate, narrow and curved. Genital shield tongue-shaped, elongated, reaches anterior margin of anal shield, expanded laterally past level of setae st5, length 145-148, maximum width 81-84, posterior margin rounded, shield reticulate ornamentation throughout, comprising elongated oblique irregular cells; bearing a pair of simple setae st5 (21-24); paragenital poroids iv5 located on soft cuticle lateral to shield near seta st5. Anal shield subtriangular, rounded anteriorly, length 55-57, width 44-50, anterior half lineate-reticulate, para-anal setae (13-15) shorter than post-anal seta (19-21), cribrum small, with 3-4 irregular rows of spicules, limited to region posterior to post-anal seta; anal poroids gv3 on anterolateral margin of anal shield. Soft opisthogastric cuticle with pair of oval metapodal plates (14-17 long $\times 2-3$ wide), and 14 pairs of smooth setae $(J v 1-J v 5, Z v 1-Z v 5, R 1-R 3$, $r 6$ ), and four pairs of poroids including $i v 5$. Exopodal and parapodal platelets fused, strip-like, extending narrowly behind coxae IV, bearing gland pore $g v 2$. Peritreme extending anteriorly to mid-level of 


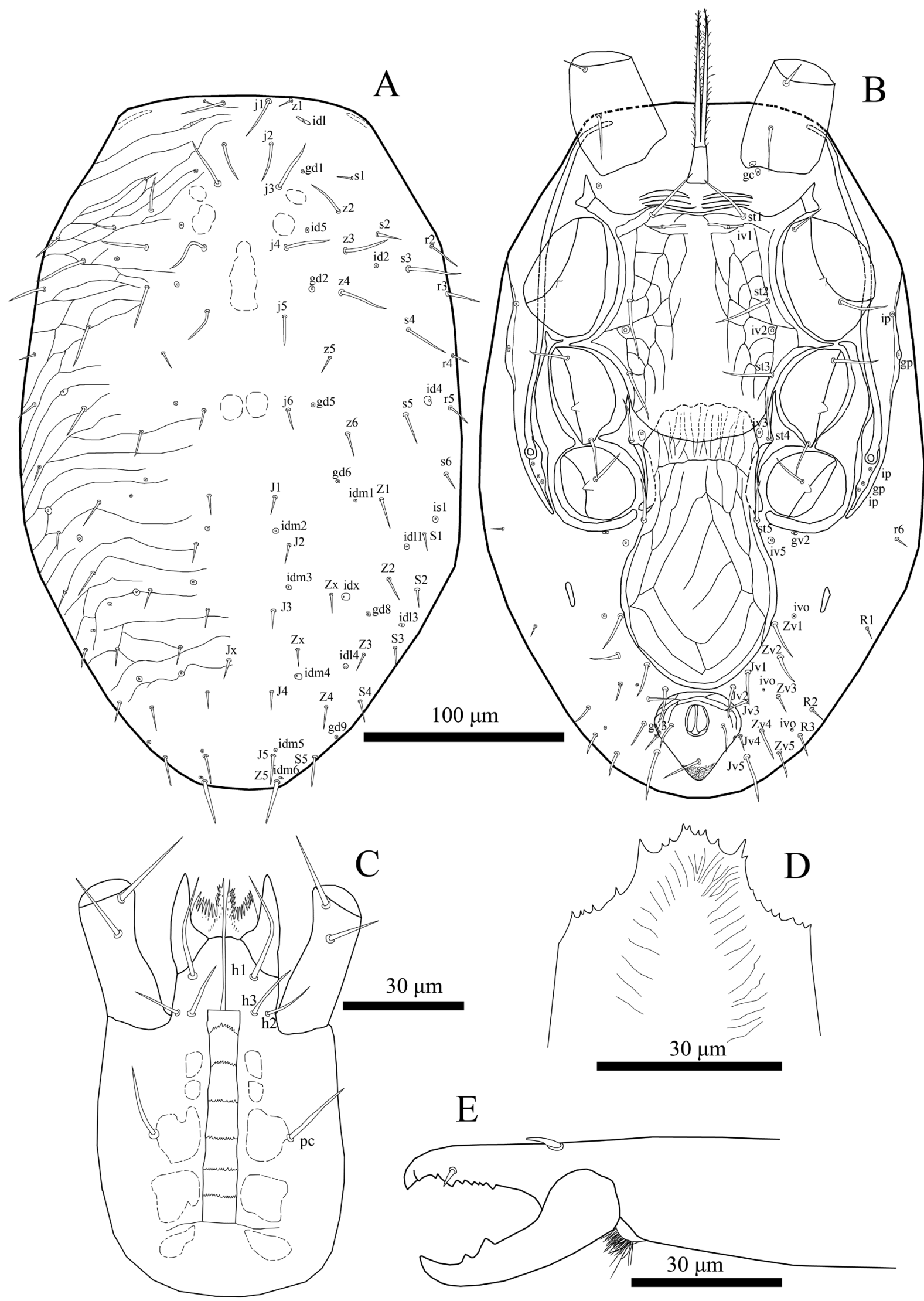

Fig. 1. Gaeolaelaps bochkovi sp.n., female: A—dorsal idiosoma, B-ventral idiosoma, C—subcapitulum, D—epistome, E-chelicera. 

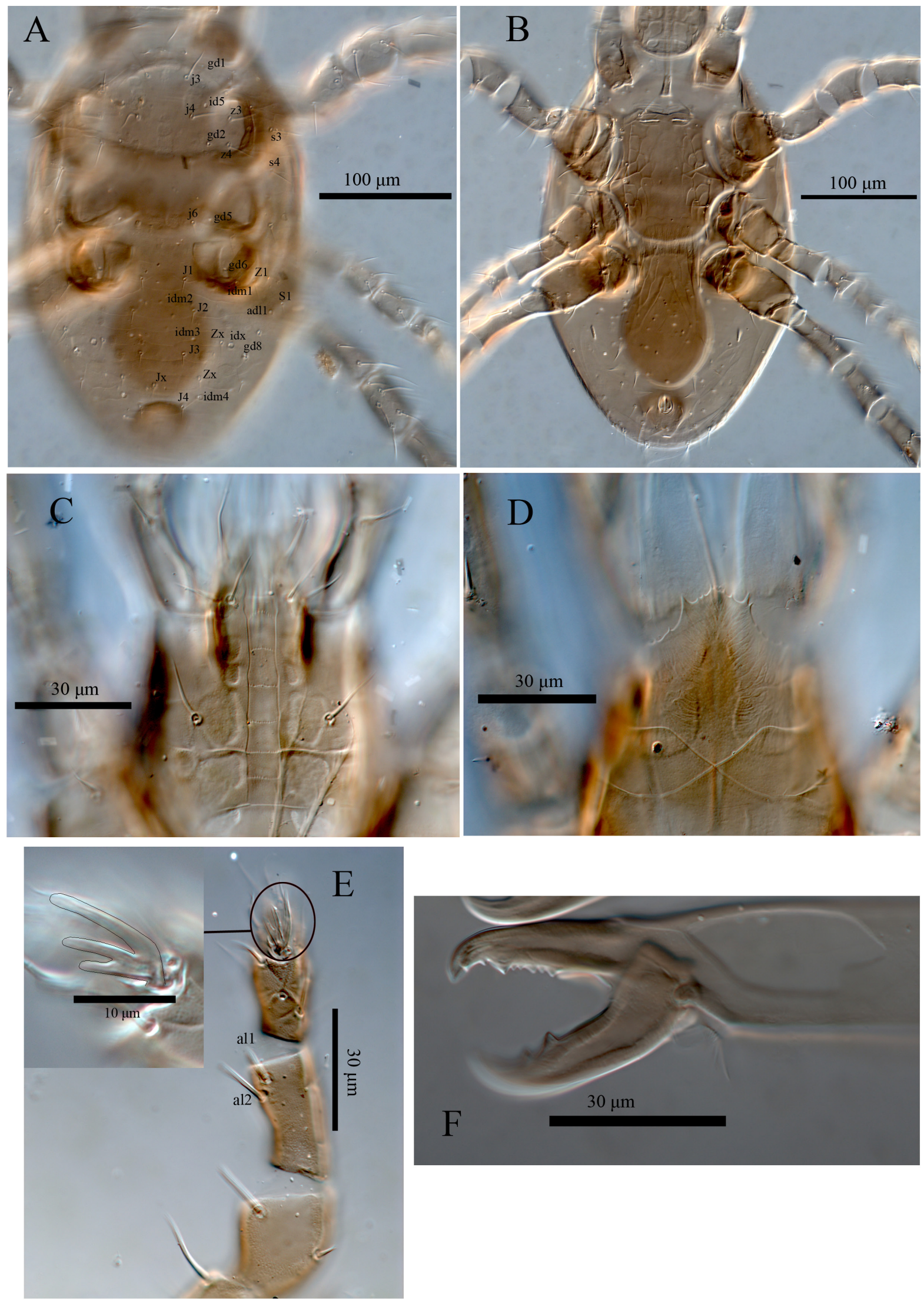

Fig. 2. DIC micrographs of Gaeolaelaps bochkovi sp. n., female: A -idiosoma in dorsal view, B - idiosoma in ventral view, $\mathrm{C}$ - subcapitulum, D — epistome, E—palp, with a focus on apotele, $\mathrm{F}$ - chelicera. 

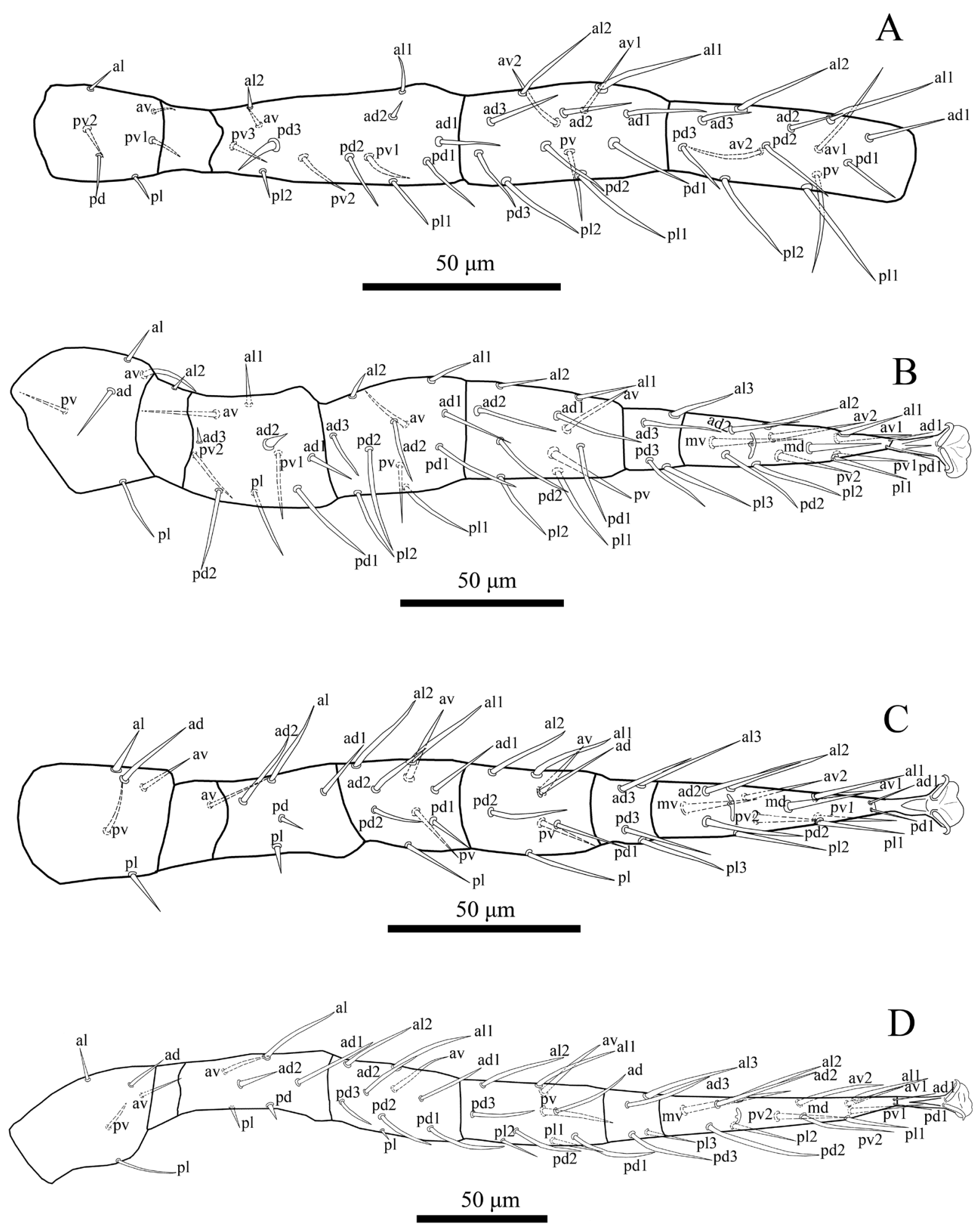

Fig. 3. Gaeolaelaps bochkovi sp.n., female: A-leg I (trochanter-tibia), B-leg II (trochanter-tarsus), C-leg III (trochanter-tarsus), D-leg IV (trochanter-tarsus).

coxa I; peritrematal shield broad on outer margin, expanded anteriorly, free from exopodal shields, each shield bearing five pore-like structures, a lyrifissure $i p$ and a gland pore $g p$ at level of coxa II and III, respectively, two lyrifissures ip and a gland pore $g p$ on post-stigmatic section (Figs. 1B, 2B).
Gnathosoma (Figs. 1C-E, 2C-F). Epistome subtriangular and irregularly denticulate (Figs. 1D, 2D). Hypostomal groove with six transverse rows of denticles, each row with 9-15 small denticles, with smooth anterior and posterior transverse lines, groove slightly wider posteriorly. Hypostome with 
four pairs of setae, $h 1$ (25-27), $h 2$ (11-13), $h 3$ (14-16), palpcoxal pc (18-20) (Figs. 1C, 2C). Corniculi robust and horn-like, extending slightly beyond palptrochanter. Chaetotaxy of palps: trochanter 2 , femur 5 , genu 6 , tibia 14 , tarsus 15 , all setae smooth and needle-like except all and al2 on palp genu thickened and apically spatulate, palp tarsal apotele three-tined (Fig. 2E). Fixed digit of chelicera with an offset and most distal tooth (gabelzhan), followed by $8-9$ variously sized teeth, a setaceous pilus dentilis, dorsal cheliceral setae prostrate, arthrodial membrane with a rounded flap and normal filaments; cheliceral lyrifissures indistinct, movable digit with two teeth (Figs. 1E, 2F).

Legs (Figs. 3A-D). Legs II (282-290) and III (252-255) short, I (379-383) and IV (386-391) longer. Chaetotaxy normal for free-living Laelapidae: Leg I (Fig. 3A): coxa 0-0/1, 0/1-0, trochanter $1-0 / 1,1 / 2-1$, femur $2-2 / 1,3 / 3-2$ ( $p d 3$ thickened), genu 2-3/2, 3/1-2, tibia 2-3/2, 3/1-2. Leg II (Fig. $3 \mathrm{~B})$ : coxa $0-0 / 1,0 / 1-0$, trochanter $1-1 / 1,0 / 1-1$, femur 2-3/1, 2/2-1 (ad2 lanceolate shape), genu 2-3/1, 2/1-2 (pd2 longest 33-35), tibia 2-2/1, 2/1-2 (all ventral setae thickened). Leg III (Fig. 3C): coxa $0-0 / 1,0 / 1-0$, trochanter $1-1 / 1,0 / 1-0$, femur $1-2 / 1$, 1/0-1, genu 2-2/1, 2/1-1 ( $a v$ thickened), tibia: $2-1 / 1$, 2/1-1 (all ventral setae thickened). Leg IV (Fig. 3D): coxa $0-0 / 1,0 / 0-0$, trochanter $1-1 / 1,0 / 1-1$, femur 1-2/1, 1/0-1 (al, ad2 longest 35-38), genu 2-2/1, 3/0-1 (av thickened), tibia 2-1/1, 3/1-2 (av and $p v$ thickened). Tarsi II-IV with 18 setae (3-3/2, $3 / 2-3+m v, m d)$; tarsus IV with elongate setae $(a d 2$, $p d 245-50$ ), see Figs. 3B, C. All pretarsi with welldeveloped paired claws, rounded pulvilli and normal ambulacral stalk.

Insemination structures: not seen, apparently unsclerotized.

Male and immatures. Unknown.

Type material examined: holotype, female, Tanzania, Zanzibar, forest litter, $06^{\circ} 16^{\prime} \mathrm{S}, 039^{\circ} 25^{\prime} \mathrm{E}$, 8 m a.s.1., 2 February 2018, coll. S.G. Ermilov, A.A. Khaustov; paratypes: 34 females, same data as holotype.

Etymology. This species is named in honour of Dr. Andrei Bochkov, who made important contributions to the systematics and phylogenetics of acariform mites. He passed away unexpectedly last year, resulting in an irretrievable loss for the international scientific community.

Differential diagnosis. The palp tarsal claw in Gaeolaelaps is usually two-tined, rarely threetined. According to Joharchi et al. (2019) and the identification key to Gaeolaelaps species provided in this publication, a three-tined tarsal claw occurs only in seven species of Gaeolaelaps. Also, in Karg's (1982) classification, Gaeolaelaps bochkovi could be placed into the schusteri species group Hypoaspis (Gaeolaelaps) based on the presence of a long genital shield and of supernumerary setae $J x$ between $J$-series. Gaeolaelaps bochkovi is most similar to Gaeolaelaps urumiensis Kavianpour et al. 2018 and Gaeolaelaps setillus Joharchi et al. 2019; however, the two species can be separated by the following combination of characters. All setae on dorsal shield minute and uniform in length in both G. urumiensis and G. setillus but posterior dorsal setae much shorter than anterior dorsal setae in G. bochkovi. Surface of sternal and genital shields with strong reticulate ornamentation throughout in G. bochkovi, but surface of sternal and genital shields finely reticulated in G. setillus. Peritrematal shield narrow and post-stigmatal section elongated, slender (ensiform) in both $G$. urumiensis and G. setillus, but peritrematal shield and post-stigmatal section expanded in G. bochkovi. There is a lanceolate-shaped seta $(a d 2)$ on femur II of $G$. bochkovi, but ad2 simple on femur II in both G. urumiensis and G. setillus.

\section{DISCUSSION}

Joharchi et al. 2018 have recorded a collection of species of soil-inhabiting laelapid mites from Zanzibar. In this paper, we have expanded this study by describing a new species from the genus Gaeolaelaps. The new species is morphologically similar to the other free-living Gaeolaelaps species. However, it possesses a rare three-tined palp tarsal claw character state, which is usually two-tined in Gaeolaelaps. At this point, including this new species, there are only eight described species within Gaeolaelaps with this rare character state. Gaeolaelaps bochkovi appears to be endemic, but it will almost certainly be found in mainland Africa when more extensive collecting is carried out there.

\section{REFERENCES}

Athias-Henriot, C. 1971. La divergence néotaxique des Gamasides (Arachnides). Bulletin Scientifique de Bourgogne, 28: 93-106.

Athias-Henriot, C. 1975. Nouvelles notes sur les Amblyseiini. II. Le relevé organotaxique de la face dorsale adulte (Gamasides, protoadéniques, Phytoseiidae). Acarologia, 17: 20-29.

Beaulieu, F. 2009. Review of the mite genus Gaeolaelaps Evans and Till (Acari: Laelapidae) and 
description of a new species from North America, G. gillespiei, n.sp. Zootaxa, 2158: 33-49.

Evans, G.O. 1963a. Observations on the chaetotaxy of the legs in the free-living Gamasina (Acari: Mesostigmata). Bulletin of the British Museum (Natural History) Zoology, 10: 277-303. DOI: 10.5962/bhl. part. 20528

Evans, G.O. 1963b. Some observations on the chaetotaxy of the pedipalps in the Mesostigmata (Acari). Annals and Magazine of Natural History, 13: 513-527. DOI: 10.1080/00222936308651393

Evans, G.O. and Till, W.M. 1966. Studies on the British Dermanyssidae (Acari: Mesostigmata). Part II. Classification. Bulletin of the British Museum (Natural History) Zoology, 14: 107-370. DOI: 10.1111/j.1096-3642.1979.tb00059.x

Evans, G.O. and Till, W.M. 1979. Mesostigmatic mites of Britain and Ireland (Chelicerata: Acari-Parasitiformes). An introduction to their external morphology and classification. Transactions of the Zoological Society of London, 35: 139-270. DOI: 10.1111/j.1096-3642.1979.tb00059.x

Joharchi, O., Halliday, B., Khaustov, A.A. and Ermilov, S.G. 2018. Some soil-inhabiting mites from Zanzibar (Acari: Laelapidae). Zootaxa, 4514 (1): 23-40. DOI: 10.11646/zootaxa.4514.1.2

Joharchi, O., Halliday, B., Tolstikov, A.V. and Trach, V.A. 2019a. New records and new species of mites from Cuba, with description of a new genus of Laelapidae (Acari: Mesostigmata). Zootaxa, 4612 (3): 326-350.

Joharchi, O., Khaustov, A.A., Tolstikov A.V. and Trach, V.A. 2019b. Rediscovery and redescription of two species of Gaeolaelaps Evans and Till (Mesostigmata: Laelapidae) from the Far East of Russia. International Journal of Acarology, 45: 1-12.

Joharchi, O., Khaustov, A.A and Ermilov, S.G. 2019c. Two new species of Gaeolaelaps Evans \& Till (Acari: Laelapidae) from Sri Lanka. Zootaxa: 4615 (3): 563-576.
Karg, W. 1982. Zur Kenntnis der Raubmilbeng Hypoaspis Canestrini, 1884 (Acarina, Parasitiformes). Mitteilungen aus dem Zoologischen Museum in Berlin, 58: 233-256.

Kavianpour, M., Nemati, A. and Karimpour, Y. 2018. A new species of Gaeolaelaps Evans \& Till (Mesostigmata: Laelapidae) from northwestern Iran with a key to the species with three-tined apotele, International Journal of Acarology, 44: 180-184. DOI: $10.1080 / 01647954.2018 .1473490$

Kazemi, S.h., Rajaei, A. and Beaulieu, F. 2014. Two new species of Gaeolaelaps (Acari: Mesostigmata: Laelapidae) from Iran, with a revised generic concept and notes on significant morphological characters in the genus. Zootaxa, 3861: 501-530. DOI: 10.11646/zootaxa.3861.6.1

Lindquist, E.E. and Evans, G.O. 1965. Taxonomic concepts in the Ascidae, with a modified setal nomenclature for the idiosoma of the Gamasina (Acarina: Mesostigmata). Memoirs of the Entomological Society of Canada, 47: 1-64. DOI: 10.4039/ entm9747fv

Prendergast, M.E., Rouby, H., Punnwong, P., Marchant, A.C., Kourampas, N., Shipton, C., Walsh, M., Lambeck, K. and Boivin, N.L. 2016. Continental island formation and the archaeology of defaunation on Zanzibar, eastern Africa. PloS One, 11 (2), e0149565.

Van Aswegen, P.I.M. and Loots, G.C. 1970. A taxonomic study of the genus Hypoaspis Canestrini sens. lat. (Acari: Laelapinae) in the Ethiopian region. Publicações Culturais Da Companhia De Diamantes De Angola, 82: 167-213.

Walsh, M.T. 2007. Island subsistence: hunting, trapping and the translocation of wildlife in the Western Indian Ocean. Azania, 42: 83-113.

Walter, D.E. and Krantz, G.W. 2009. Collecting, rearing and preparing specimens. In: G.W. Krantz and D.E. Walter (Eds.). A Manual of Acarology. $3^{\text {rd }}$ edition. Texas Tech University Press, Lubbock, Texas, pp. 83-95. 